\title{
STATUS ZINC PADA LANSIA LAKI-LAKI YANG ANEMIA DAN TIDAK ANEMIA DI DESA DAN KOTA
}

\author{
Yuniar Rosmalina'; Dewi Permaesih ${ }^{1}$ dan Fitrah Ernawati ${ }^{1}$ \\ ${ }^{1}$ Pusat Penelitian dan Pengembangan Gizi dan Makanan, Bogor \\ Badan Litbang Kesehatan, Dep.Kes R.I
}

\section{ABSTRACT \\ ZINC STATUS OF ANEMIC AND NON-ANEMIC MALE ELDERLY IN RURAL AND URBAN AREAS}

The elderly peoples are prone to micronutrients deficiency such as zinc. The impact of low intake of zinc is impaired functions of wound healing, immunity and taste and smell. The article presents the zinc state of elderly people with or without anemia. The age of subjects was $60-75$ years. physically and clinically healthy, and agreed to participate in this study. Data collection including anthropometric measurements (body weight, height, mid-upper circumference), zinc, and $\mathrm{Hb}$. Body Mass Index was calculated using ratio body weight to height. Hemoglobin level was analyzed using cyanmethemoglobin method and serum zinc was analyzed using Atomic Absorption Spectrophotometer method. The average Body weight, height and MUAC of urban elderly were statistically higher compared to rural elderly. The proportion of anemic among elderly in rural was 29.0 percent and 15.7 percent in urban. Serum zinc level showed that the proportion of elderly who have low serum zinc level was higher in rural compared to urban area $(76.0 \%$ vs $54.9 \%$ ). Out of 54 elderly whose anemic 87.1 percent have serum zinc level below $70 \mathrm{mg} / \mathrm{L}$, while in urban area out of 64 anemic elderly $68.8 \%$ have serum zinc level below $70 \mathrm{mg} / \mathrm{L}$. The proportion of elderly who have suffered anemia and have low serum level were higher in rural compared to urban area.

Keywords: anemia, zinc, elderly

\section{PENDAHULUAN}

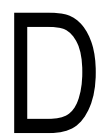

efisiensi berbagai mikronutrien banyak dijumpai di Indonesia. Lansia merupakan salah satu kelompok yang rawan terhadap kekurangan zat gizi mikro seperti zinc. Dampak kekurangan zinc pada lanjut usia (Lansia) adalah penurunan fungsi kekebalan tubuh, penurunan daya pengecapan dan penciuman terhadap makanan dan juga bisa memperpanjang masa penyembuhan penyakit ${ }^{(1)}$.

Banyak faktor yang berperan terhadap Lansia dari resiko kekurangan zinc, yaitu menurunnya intake zat gizi, menurunnya kebutuhan energi, adanya depresi atau faktor kesepian dan rendahnya konsumsi makanan sumber zinc itu sendiri. Adanya problem gigi geligi dan kemiskinan menyebabkan ketidakmampuan membeli dan mengkonsumsi bahan makanan sumber zinc seperti ikan atau daging ${ }^{(2)}$.

Anemia pada Lansia di negara-negara maju bukanlah merupakan masalah terutama pada Lansia laki-laki. Hasil penelitian menunjukkan ternyata ada perbedaan proporsi anemia di desa dan di kota. Proporsi anemia Lansia di daerah kota lebih rendah dibandingkan Lansia di desa. Proporsi anemia di kota Jakarta dan Bogor proporsinya di bawah 15 persen, tapi untuk daerah perdesaan Bogor proporsinya berkisar antara 25.0 - 30 persen ${ }^{(3,4)}$.

Adanya interaksi antara zinc dengan mineral lain seperti zat besi telah banyak dipublikasi. Namun hal ini tergantung dari ikatan zinc tersebut dan jumlah dan jenis zat besi yang diberikan ${ }^{(5)}$. 
Data status zinc pada Lansia $\mathrm{d}$ Indonesia masih terbatas dan tulisan ini menyajikan gambaran status zinc di kota dan desa serta kaitannya dengan status anemianya.

\section{BAHAN DAN CARA}

Analisis ini menggunakan data dasar penelitian " Faktor-faktor Negative Deviance yang berkaitan dengan tingkat kesegaran jasmani pada Lansia tidak anemia".

\section{Lokasi Penelitian dan Sampel}

Penelitian dilakukan di Kecamatan Ciampea yang mewakili Desa yaitu meliputi: Kelurahan Situ Daun, Kelurahan Cinangka dan Kelurahan Benteng. Sedangkan Kecamatan Tebet Jakarta mewakili Kota yaitu meliputi Kelurahan Manggarai Selatan, Bukit Duri dan Menteng Dalam. Pengumpulan data dilakukan mulai bulan April 2002 hingga Oktober 2002.

Responden adalah Lansia laki-laki dengan umur 60 tahun ke atas, dengan kriteria sehat secara fisik dan klinis serta bersedia ikut dalam penelitian. Jumlah responden adalah 379 orang Lansia laki-laki di desa dan 428 orang Lansia laki-laki di kota.

\section{Data yang Dikumpulkan}

Berat badan diukur dengan menggunakan timbangan digital Seca dengan ketelitian $0.1 \mathrm{~kg}$. Tinggi badan diukur menggunakan alat microtoise dengan ketelitian $0.1 \mathrm{~cm}$. Lingkar Lengan Atas diukur menggunakan pita LLA dengan ketelitian $0.1 \mathrm{~cm}$. Indeks Massa Tubuh dihitung berdasarkan rasio antara berat badan $(\mathrm{kg})$ terhadap tinggi badan $(\mathrm{m})$ kuadrat ${ }^{(6)}$.

Status besi ditentukan dengan cara pemeriksaan kadar hemoglobin darah menggunakan metoda cyanmethemoglobin. Batasan anemia bila kadar hemoglobin < $13.0 \mathrm{~g} / \mathrm{dl}^{\left({ }^{(7)}\right.}$. Status zinc ditentukan dengan pemeriksaan serum zinc menggunakan metoda Atomic Absoprtion Spectrophotometry (AAS). Batasan defisiensi zinc bila kadar serum zinc $<70 \mathrm{ug} / \mathrm{L}^{(8)}$.

Status kesehatan didasarkan pada pemeriksaan secara klinis secara umum dan riwayat kesehatan dahulu dan sekarang dilakukan oleh dokter. Pemeriksaan WBC (white blood cell) dilakukan untuk memastikan responden pada saat pemeriksaan tidak sedang menderita sakit infeksi.

\section{Pengolahan dan Analisis data}

Data dianalisis untuk mengetahui sebaran dan nilai rata-rata. Hubungan dua variabel dianalisis dengan Chi-square .

\section{HASIL}

Jumlah responden Lansia yang turut serta dalam penelitian ini yaitu 807 orang dan sebarannya menurut kelompok umur dapat dilihat pada Tabel 1 .

Tabel 1

Sebaran umur responden di desa dan kota

\begin{tabular}{|c|c|c|c|c|c|c|}
\hline \multirow{2}{*}{ Umur } & \multicolumn{2}{|c|}{ Desa } & \multicolumn{2}{c|}{ Kota } & \multicolumn{2}{c|}{ Total } \\
\cline { 2 - 7 } & $\mathrm{n}$ & $\%$ & $\mathrm{n}$ & $\%$ & $\mathrm{n}$ & $\%$ \\
\hline $60-64$ th & 117 & 30.9 & 152 & 35.5 & 269 & 33.3 \\
$65-69$ th & 67 & 17.7 & 123 & 28.7 & 190 & 23.5 \\
$\geq 70$ th & 195 & 51.5 & 153 & 35.7 & 348 & 43.2 \\
\hline Total & 379 & 100 & 428 & 100 & 807 & 100 \\
\hline
\end{tabular}

Tabel di atas memperlihatkan sebaran umur Lansia laki-laki antara desa dan kota berbeda. Proporsi umur Lansia di desa tertinggi adalah kelompok umur di atas umur 
70 tahun yaitu 51.5 persen sedangkan di kota proporsi Lansia kelompok umur $60-64$ tahun sama proporsinya dengan kelompok umur $\geq 70$ tahun yaitu sekitar 35 persen.

Tabel 2

Rata-rata dan simpang baku pengukuran anthropometri menurut desa dan kota*

\begin{tabular}{|l|c|c|}
\hline \multicolumn{1}{|c|}{ Pengukuran } & Desa $(\mathrm{n}=379)$ & Kota $(\mathrm{n}=425)$ \\
\hline Berat badan $(\mathrm{kg})$ & $47.0 \pm 7.4$ & $56.9 \pm 11.3$ \\
Tinggi badan $(\mathrm{cm})$ & $156.4 \pm 6.2$ & $159.6 \pm 5.7$ \\
Lingkar lengan atas $(\mathrm{cm})$ & $24.3 \pm 2.9$ & $25.8 \pm 3.4$ \\
Indeks Massa Tubuh & $19.2 \pm 2.6$ & $22.3 \pm 3.9$ \\
\hline
\end{tabular}

*berbeda bermakna $p<0.05$

Hasil pengukuran antropometri menunjukkan rata-rata berat badan, tinggi badan, lingkar lengan atas dan IMT lebih tinggi pada Lansia yang tinggal di kota dan hasil analisis menunjukkan perbedaan yang bermakna.

Hasil analisis status besi dan zinc pada Lansia dapat dilihat pada Tabel 3.

Tabel 3.

Rata-rata kadar hemoglobin dan zinc pada Lansia anemia dan tidak anemia

\begin{tabular}{|l|c|c|c|c|}
\hline \multicolumn{1}{|c|}{ Wilayah } & \multicolumn{2}{|c|}{ Anemia } & \multicolumn{2}{c|}{ Tidak anemia } \\
\hline Desa & $\mathrm{n}$ & & $\mathrm{n}$ & \\
Hemoglobin $(\mathrm{g} / \mathrm{dl})^{*}$ & 110 & $11.9 \pm 0.97$ & 269 & $14.2 \pm 0.88$ \\
Zinc $(\mathrm{mg} / \mathrm{L})^{*}$ & 54 & $58.9 \pm 12.7$ & 175 & $63.5 \pm 12.8$ \\
\hline Kota & & & & \\
Hemoglobin $(\mathrm{g} / \mathrm{dl})^{*}$ & 67 & $12.1 \pm 0.70$ & 361 & $14.9 \pm 0.94$ \\
Zinc $(\mathrm{mg} / \mathrm{L})^{*}$ & 64 & $65.2 \pm 14.9$ & 342 & $69.7 \pm 11.5$ \\
\hline
\end{tabular}

*berbeda bermakna $p<0.05$

Tabel 3 menunjukkan rata-rata kadar hemoglobin dan kadar zinc Lansia yang anemia baik di desa maupun kota lebih rendah secara bermakna dibandingkan dengan Lansia tidak anemia. Namun kadar zinc rata-rata Lansia yang tidak anemia menunjukkan masih dibawah "cut-off point" < $70 \mathrm{mg} / \mathrm{L}$ atau menderita defisiensi zinc.

Berdasarkan batasan anemia pada Lansia <= $13.0 \mathrm{~g} / \mathrm{dl}$ dan defisiensi zinc $<=70$ $\mathrm{mg} / \mathrm{L}$ maka proporsi Lansia yang anemia dan menderita defisiensi zinc dapat dilihat pada Gambar di bawah ini. 


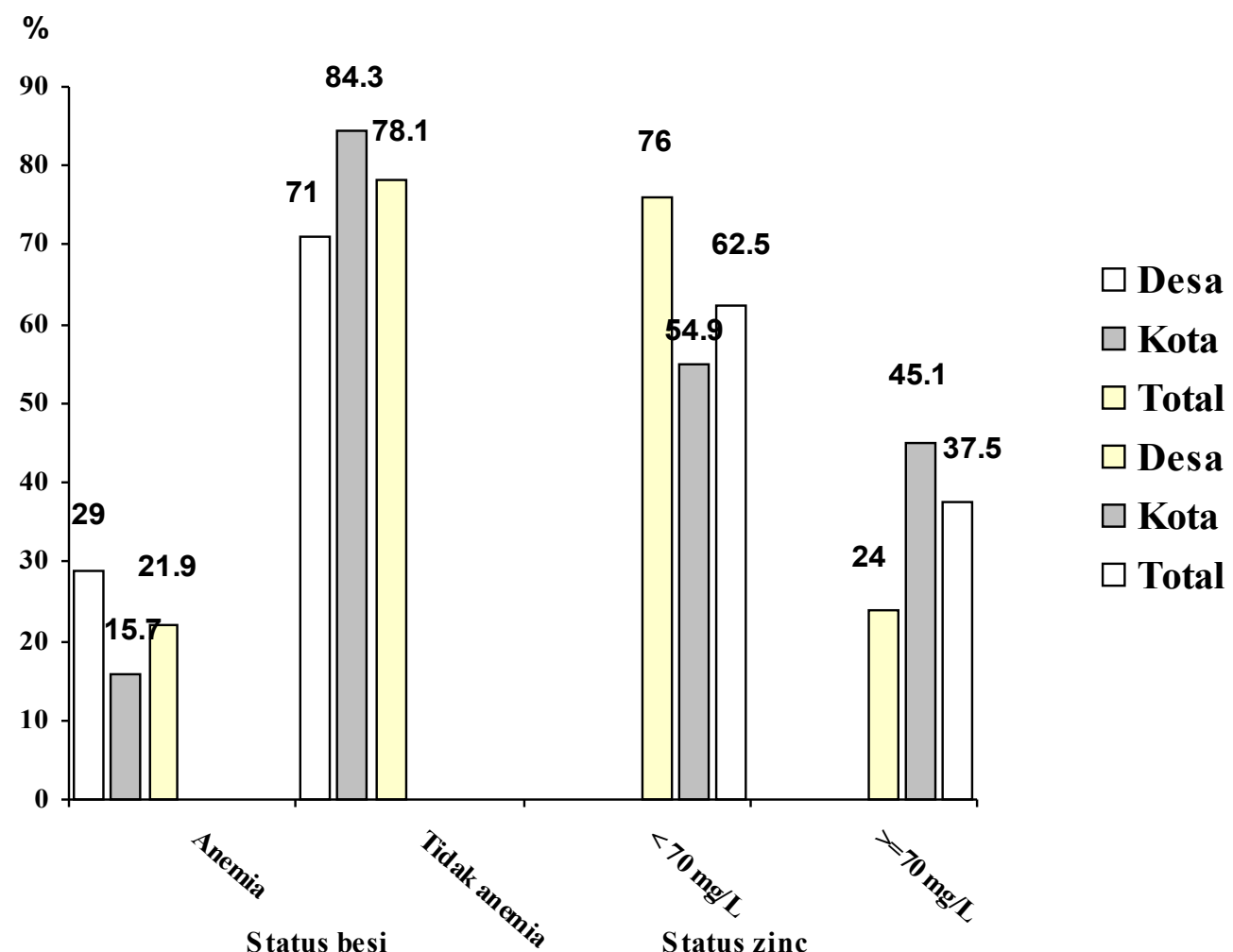

Gambar 1. Proporsi anemia dan zinc status pada Lansia di desa dan kota

Gambar 1 menunjukkan proporsi anemia di desa terlihat lebih tinggi yaitu 29.0 persen dibandingkan dengan Lansia di kota hanya 15.7 persen. Demikian juga Lansia yang menderita defisiensi zinc terlihat lebih tinggi di desa yaitu 76.0 persen dibandingkan di kota yang hanya 54.9 persen.

Tabel 4. memeperlihatkan proporsi Lansia berdasarkan status zinc pada Lansia laki-laki yang menderita anemia dan tidak anemia.

Tabel 4

Proporsi status zinc pada Lansia yang anemia dan tidak anemia

\begin{tabular}{|l|c|c|c|c|c|c|}
\hline \multirow{2}{*}{ Wilayah } & \multicolumn{2}{|c|}{ Anemia } & \multicolumn{2}{c|}{ Tidak anemia } & \multicolumn{2}{c|}{ Total } \\
\cline { 2 - 7 } & $\mathrm{n}$ & $\%$ & $\mathrm{n}$ & $\%$ & $\mathrm{n}$ & $\%$ \\
\hline Desa & & & & & & \\
Zinc $<70 \mathrm{mg} / \mathrm{L}$ & 47 & 87.0 & 127 & 72.6 & 174 & 76.0 \\
Zinc $\geq 70 \mathrm{mg} / \mathrm{L}$ & 7 & 13.0 & 48 & 27.4 & 55 & 24.0 \\
\hline Kota & & & & & & \\
Zinc $<70 \mathrm{mg} / \mathrm{L}$ & 44 & 68.8 & 179 & 52.3 & 223 & 54.9 \\
Zinc $\geq 70 \mathrm{mg} / \mathrm{L}$ & 20 & 31.2 & 163 & 47.7 & 183 & 45.1 \\
\hline
\end{tabular}


Tabel di atas menunjukkan dari 54 orang Lansia di desa yang menderita anemia 87.0 persen mempunyai kadar zinc di bawah $70 \mathrm{mg} / \mathrm{L}$, sedangkan di kota dari 64 orang yang menderita anemia 68.8 persen mempunyai kadar zinc dibawah $70 \mathrm{mg} / \mathrm{L}$.

\section{BAHASAN}

Lansia merupakan kelompok yang rawan terhadap gangguan kesehatan dan kekurangan gizi karena dengan meningkatnya usia fungsi-fungsi organ tubuh juga menurun.

Hasil penelitian terhadap Lansia laki-laki di desa dan di kota ini menunjukkan proporsi Lansia yang menderita anemia di desa lebih tinggi dibandingkan Lansia di kota ( $29 \%$ vs 15.7\%). Hasil tersebut sejalan dengan penelitian pada Lansia sebelumnya. Proporsi anemia di kota berkisar antara $12-15$ persen. Di negara-negara maju anemia pada Lansia bukanlah merupakan masalah yang besar, prevalensinya hanya 10 persen $(3,4)$.

Hasil penelitian ini juga menunjukkan Lansia yang menderita defisiensi zinc persentasenya cukup tinggi yaitu 62.5 persen. Persentase Lansia yang menderita defisiensi di desa 20 persen lebih tinggi dibandingkan dengan Lansia di kota. Keadaan ini ternyata ada hubungan yang positif antara status besi dan zinc yang digambarkan pada tabel 4 yaitu dari 54 Lansia yang anemia di desa 87 persen juga menderita defisiensi zinc dan dari 64 Lansia di kota yang anemia 68.8 persen menderita defisiensi zinc. Hal ini bisa disebabkan karena akses Lansia di kota terhadap makanan sumber zinc lebih baik. Kondisi sosial ekonomi Lansia di desa menyebablkan mereka tidak mampu membeli bahan pangan hewani. Sumber pangan Lansia di desa adalah dari nabati yang kandungan fitatnya cukup tinggi. Dalam penyerapan zinc, fitat merupakan zat yang bisa menghambat. Protein hewani bisa memperbaiki penyerapan zinc dari pengaruh fitat (7). Namun penelitian lain mengemukakan bahwa asupan zinc pada Lansia memang selalu rendah bahkan pada
Lansia dengan kondisi sosial ekonomi yang lebih tinggi. Menurunnya aktifitas fisik karena sudah tidak aktif bekerja berakibat menurunnya total asupan makanan yang secara langsung berperan dalam menurunnya asupan mikronutrient seperti zinc dan zat besi (9). Selain itu defisiensi zinc juga dapat diakibatkan karena menurunnya fungsi organ yang mengabsorbsi zat zinc karena faktor usia (10). Dan ini terlihat pada Tabel 1 bahwa sebaran umur Lansia lebih tinggi pada kelompok umur di atas 70 tahun. Suplementasi zinc pada Lansia apakah mungkin diperlukan tentu memerlukan kajian yang lebih komprehensif.

Dibandingkan dengan defisiensi zinc, proporsi anemia pada Lansia laki-laki ini lebih rendah yaitu di kota hanya 15 persen dan di desa 29 persen. Di sini tidak bisa dipaparkan secara nyata apakah ada interaksi antara zinc dan zat besi namun hasil analisis hubungan secara korelasi menunjukkan ada hubungan yang positif antara kadar zinc dan kadar hemoglobin. Hasil penelitian Prasad menyatakan bahwa bila kelebihan zat besi memang akan memberi dampak terhadap defisiensi zinc ${ }^{(5)}$.

\section{KESIMPULAN}

1. Proporsi anemia Lansia laki-laki lebih tinggi di desa dibandingkan dengan di kota.

2. Defisiensi zinc pada Lansia laki-laki proporsinya lebih tinggi di desa dibandingkan dengan Lansia di kota.

3. Proporsi Lansia laki-laki yang menderita defisiensi zinc lebih tinggi pada Lansia yang anemia.

\section{SARAN}

Melihat proporsi anemia dan defisiensi zinc pada Lansia di desa lebih tinggi, maka perlu dilakukan upaya-upaya untuk peningkatan status zat gizi Lansia di desa. 


\section{UCAPAN TERIMA KASIH}

Terima kasih yang sebesar-besarnya kami ucapkan kepada Bapak Lurah Situ Daun, Cinangka, Benteng beserta staf di Kecamatan Ciampea atas segala bantuan dan kerjasamanya. Ucapan terima kasih juga kami sampaikan kepada Bapak Lurah Manggarai Selatan, Bukit Duri dan Menteng Dalam beserta staf di Kecamatan Tebet atas segala bantuan dan kerjasamanya. Penghargaan yang setingi-tingginya juga kami sampaikan pada bapak-bapak Lansia atas kesediaannya turut serta dalam kegiatan ini.

\section{RUJUKAN}

1. Sandstead,H.H. et al. Zinc Nutrition in The Elderly in relation to Taste Aquity, Immune Response and Wound Healing. Amer.J.of Clin.Nutr 36, 1982. 1046 59 .

2. WHO, (1996). Trace Elements in Human Nutrition and Health.

3. Rosmalina,Y. (1997). Effects of Micronutrient supplementation on Immune Status and Hand grip strength of Male Elderly People in Kelurahan Cempaka Putih Barat,Jakarta. Masterial
Thesis. Postgraduate Program University of Indonesia.

4. Rosmalina.Y. Laporan Penelitian faktorfaktor yang mempengaruhi "Muscle strength" pada Lansia laki-laki. 1999.

5. Prasad,A.S. Interactions of Zinc with Other Micronutrient dalam Biochemistry of Zinc. Plenum Press.New York and London. 1993.

6. WHO.Technical Report Series. Physical status: The Use and Interpretation of Anthropometri. Report of a WHO Expert Committee. Geneva 1995.

7. WHO. Iron Deficiency Anaemia. Assessment, Prevention and Control. A Guide for Programme Manager. 2001.

8. Gibson RS. Principle of Nutritional Assessment.New York. Oxford University Press.1990.

9. Hotz, C, and Kenneth H. Brown . Assessment of The Risk of Zinc Deficiency in Populations and Options for Its Control. Food and Nutrtion Bulletin. Volume 25, Number 3. 2004.

10. Couzy, $F$ et al. Zinc Absoption in Healthy Elderly Humans and The Effect of Diet. Am.J.Clin.Nutr $1993 ; 58$ : 690694. 